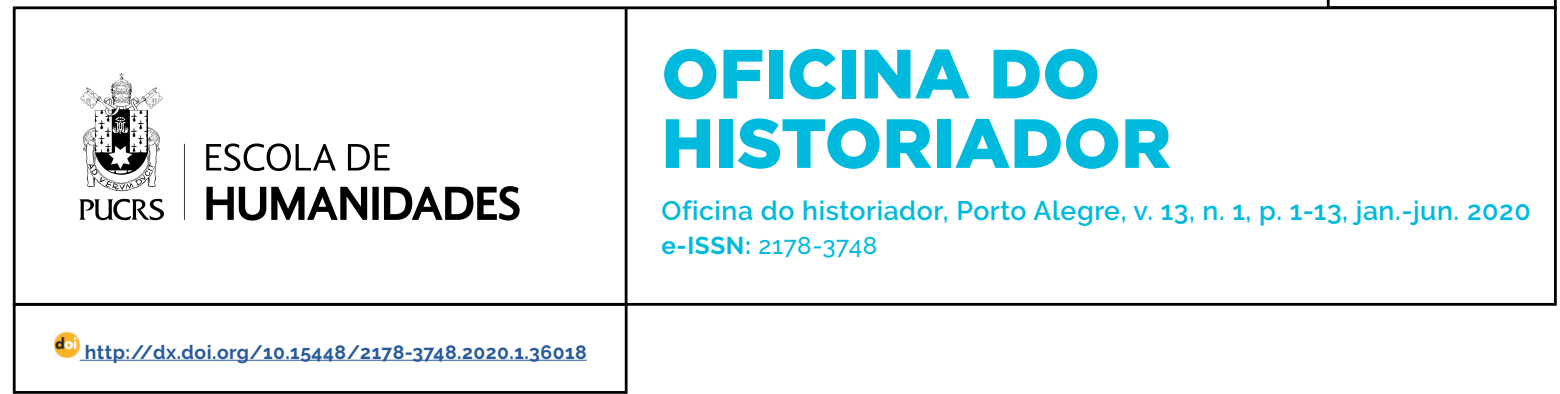

SEÇÃO: ARTIGOS

\title{
Extinguindo o "infame" comércio de escravos no império brasileiro
}

\author{
Extinguishing the "infame" slave trade in the brazilian empire
}

\author{
Ana Priscila de Sousa Sá ${ }^{1}$ \\ orcid.org/0000-0002-0048-280X \\ priscilareds@hotmail.com
}

Recebido em: 17 out. 2019. Aprovado em: 16 dez. 2019. Publicado em: 14 jun. 2020.
Resumo: O artigo analisou a proposta de extinção do tráfico de escravos para - Brasil realizada pelo historiador brasileiro Francisco Adolfo de Varnhagen no Memorial orgânico (1849-1850-1851). Em um contexto de pressão inglesa pela sua supressão e intenso debate sobre a escravidão e seu impacto sobre a vida social, econômica do País na metade do século XIX, Varnhagen defendeu a necessidade de se findar essa prática secular como uma das formas de auxiliar no desenvolvimento do Império, colocando-o na posição de nação forte e respeitável perante o mundo civilizado. Para tanto, fez-se necessário tratar com mais vagar da conjuntura política brasileira à época e como as questões do tráfico e da escravidão apareciam nos debates entre figuras destacadas do cenário letrado como José Bonifácio de Andrada e Silva, Bernardo Pereira de Vasconcelos e Tavares Bastos. O conteúdo do Memorial orgânico, portanto, demonstrava o quanto o historiador paulista estava atualizado com a agenda política do Império do Brasil em meados do oitocentos, usando sua experiência técnica para tratar de uma questão tão premente. Em 1850, pela Lei Eusébio de Queiroz, o tráfico de escravos para o Brasil foi finalmente abolido, a pressão britânica, mas também o medo de rebeliões, o surto de febre amarela associado com o tráfico e uma opinião interna antiescravista contribuiram para que essa medida saisse do papel naquele momento de consolidação do poder imperial no Segundo Reinado.

Palavras-chave: Varnhagen. Tráfico de escravos. Império do Brasil.

Abstract: The article analyzed the proposal of extinction of the slave trade to Brazil made by the Brazilian historian Francisco Adolfo de Varnhagen at the Memorial orgânico (1849-1850-1851). In a context of English pressure for its suppression and intense debate about slavery and its impact on the country's social and economic life in the mid-nineteenth century, Varnhagen defended the need to end this secular practice as one of the ways to assist in the development of slavery. Empire, placing it in the position of strong and respectable nation before the civilized world. To this end, it was necessary to deal more slowly with the Brazilian political conjuncture at the time and how the issues of trafficking and slavery appeared in the debates between prominent figures of the literate scenario such as José Bonifácio de Andrada e Silva, Bernardo Pereira de Vasconcelos and Tavares Bastos. The content of the Memorial, therefore, demonstrated how well the São Paulo historian was up to date with the political agenda of the Empire of Brazil in the mid-1800s, using experience as a historian to address such a pressing issue. In 1850, under the Eusébio de Queiroz Law, the slave trade to Brazil was finally abolished, British pressure, but also the fear of rebellion, the yellow fever outbreak associated with trafficking and an anti-slavery internal opinion contributed to this measure get out of the role at that time of consolidation of imperial power in the Second Reign.

Keywords: Varnhagen. Trafficking of slaves. Empire of Brazil. 


\section{Introdução}

Entre 1849 e 1850, o historiador brasileiro Francisco Adolfo de Varnhagen ${ }^{2}$ redigiu e publicou o Memorial orgânico, em Madri, onde trabalhava como diplomata a serviço do Império do Brasil, reeditando-o em 1851 na revista Guanabara, do Rio de Janeiro. Consistindo na análise e proposição de seis medidas para a organização do território e da população do Pais, as propostas foram: nova divisão das provincias e melhoria das comunicações entre elas, mudança da capital para o interior, civilização dos índios por tutela, extinção do tráfico e imigração europeia.

O presente artigo se debruçou sobre a proposta de fim do tráfico de escravos para o Brasil. Para tanto, fez-se necessário tratar com mais vagar da conjuntura política brasileira à época e como as questões do tráfico e da escravidão apareciam nos debates entre figuras destacadas do cenário letrado. No essencial, a ideia se inseria em um contexto de pressão da Inglaterra pela supressão daquele e as discussões em torno de sua influência na corrupção dos costumes e enquanto entrave à civilização.

\section{Tráfico e escravidão no Brasil I mperial}

Na década de 1820, os eventos ligados ao processo de Independência contribuiram com novos elementos para o debate político. A discussão em torno da criação de uma identidade brasileira ou de uma nacionalidade passou a contar com enfoques inexistentes até então, remetendo à homogeneização do povo e à busca de novas formas de exploração do trabalho, escravo, imigrante ou dos indios.
De alguma forma, a escravidão era o preço que a Monarquia pagava ao latifúndio para esse apoiar-lhe em seu projeto nacional ( $\mathrm{LYNCH}, 2010$, p. 36-37). Varnhagen se dizia contrário à escravidão, mas não chegou a propor sua abolição em curto prazo. No Memorial orgânico, propôs a cessação do tráfico e a concessão de liberdade aos nascituros, acreditando que com medidas graduais o problema seria resolvido em algum ponto incerto do futuro (como acabou acontecendo!), sem prejuízo para - País, sua constante preocupação. Aliás, não apenas sua. A escravidão e a supressão ou a permanência do tráfico foi assunto sobre o qual muito se discutiu. Apareceu no Memorial orgânico, nas sociedades, gabinetes, jornais, escrivaninhas, no Governo e na rua. Assim sendo, revisamos para esse debate, as percepções de alguns politicos e homens de letras.

José Bonifácio de Andrada e Silva apontara a preguiça como caracteristica inerente aos africanos na "Representação à Assembleia Geral Constituinte e Legislativa do Império do Brasil sobre a escravatura" (1823). Bradando que o Brasil era a única nação de "sangue europeu" que ainda comerciava "clara e publicamente" escravos africanos, associou a permanência da escravidão com o costume e a "voz da cobiça" (SILVA, 1998, p. 47-60), afirmando que ela não concorria para o aumento populacional do Brasil, obstava a indústria e, ainda, viciava a sociedade. Um aspecto tocado pelo autor que merece destaque foi seu ataque ao argumento da defesa do regime como defesa da propriedade, o que já era avançado para a época. José Bonifácio alegou que quem se apoiava nesse principio defendia a força e

\footnotetext{
2 Francisco Adolfo de Varnhagen nasceu em Sorocaba, interior de São Paulo, no dia 17 de fevereiro de 1816, nas terras da Real Fábrica de Ferro de São João de Ipanema em que seu pai, o engenheiro alemão Friedrich Ludwig Wilhelm Varnhagen, foi diretor e um dos pioneiros na fundição de ferro no Brasil. Em 1823, sua mãe D. Maria Flávia de Sá Magalhães e os filhos foram ao encontro de Friedrich Varnhagen em Portugal. No final de 1825. Francisco Adolfo entrou para o Real Colégio Militar da Luz (Lisboa), concluindo em 1832. Matriculou-se na Academia da Marinha e em 1834 findou os estudos militares na Academia de Fortificações. Também frequentou outros cursos como Química, Botânica, Mineralogia, Física, Zoologia, Paleografia e Diplomática, demonstrando desde já um interesse pela pesquisa de arquivo. Foi colaborador de periódicos influentes no cenário letrado português como o jornal O Panorama e a Revista Universal Lisbonense. Foi nomeado sócio do Instituto Histórico e Geográfico Brasileiro (IHGB) logo em 1840, publicando inúmeros artigos na revista da agremiação. Durante mais de três décadas exerceu cargos na diplomacia imperial brasileira, prestando serviço em: $1842-1847$ : Lisboa/Portugal; 1847-1858: Madri/Espanha; 1859: Paraguai; 1861-1863: Venezuela (cumulativamente com a representação na Colômbia e Equador); 1863-1867: Peru (cumulativamente com Chile e Equador); 1868-1878: Viena/Áustria. Sua última visita ao Brasil se deu em 1877. vindo a falecer em junho do ano seguinte na capital do Império Austro-Húngaro, onde era Ministro Plenipotenciário, aos 62 anos de idade. De sua vasta e variada obra destacam-se o Florilégio da poesia brasileira (1850), a História Geral do Brasil (1854,1857), a História das lutas com os holandeses no Brasil desde 1624 a 1654 (1871). A origem turaniana dos americanos tupis-caraibas e dos antigos egipcios. Indicado pela filologia comparada: traços de uma antiga migração na América, invasão do Brasil pelos tupis etc. (1876), e a póstuma História da Independência (1916). Ver: LESSA, 1945, 1954, 1955
} 
não a propriedade, pois, não sendo "coisa", um homem não podia ser tratado como propriedade de outrem. Mais que a propriedade, a lei tinha que defender a liberdade pessoal dos homens.

Muitas das ideias expostas por José Bonifácio estiveram presentes na reflexão de outros personagens importantes do pensamento político brasileiro oitocentista. Em 1834, Diogo Antônio Feijó reputou como impossivel o querer acabar "de um jato" com o tráfico, tendo em vista o estado de atraso da agricultura e dos hábitos e opiniões dos patrícios. Feijó entendia que o "ato iníquo" da escravidão, além de ser uma "aberração do caminho da justiça'" e um "fato contrário à natureza e ao Evangelho" (FEIJÓ, 1999, p. 152154), desonrava a civilização do País. Também era partidário da extinção gradual e segundo a origem do escravo vendido, tomando as precauções ditadas pela prudência e a política, pensando na sociedade e no escravo. Uma proposta do Padre foi o estabelecimento de escolas normais de agricultura em todas as províncias, com o engajamento de colonos estimulado pelo Governo.

Outro que destacou a contradição com os principios liberais do sistema de liberdade constitucional que animava as instituições no Império foi Hipólito José da Costa. Como querer uma nação livre e manter dentro de si a escravidão? Para essa questão, deu uma solução binária: ou o Brasil nunca seria um povo livre ou que a escravatura fosse extinta, sua coexistência só poderia ser danosa. Para que uma existisse, a outra deveria deixar de existir. Negou "redondamente" a justificativa segundo a qual sem o braço escravo os ramos essenciais da indústria desapareceriam, levando junto a riqueza do País. Como postulado por Feijó e tantos mais, inclusive Varnhagen, o "mal" da escravidão só deveria ser remediado gradualmente e com muita prudência, auxiliado pela "boa razão" da pena dos escritores, que dirigiam a opinião pública e, com isso, faziam um relevante serviço à pátria; destruí-la de uma vez seria uma "desesperada medida de um louco" (COSTA, 2001, p. 571-573), comentou.

O jornalista apelou para a consciência dos brasileiros de "nobres almas" e "sentimentos elevados", associando a permanência da escravidão à falta de educação virtuosa das famílias, pois um homem educado com escravos olharia o despotismo como uma ordem de coisas natural, habituando-se a enxergar o seu inferior como escravo e, consequentemente, tendo um superior que o tratasse como escravo. Mais tarde. também para Tavares Bastos a escravidão era a causa mais eficaz da miséria moral e material do Brasil (BASTOS, 1975, p. 264).

Havia, porém, posicionamentos diferentes. Um arauto desses foi o Bispo Azeredo Coutinho, para quem,

[...] há alguns senhores que, esquecidos dos principios da humanidade, os tratam com dureza; mas estes senhores são mais raros do que comumente se pensa, e não devem contrabalançar àqueles que, guiados por princípios pios e humanos, tratam os seus escravos com comiseração, cujo número por felicidade cada vez mais se aumenta, à medida que as luzes se multiplicam.

Nós sabemos que, por uso geral, os fazendeiros, quando compram escravos, o primeiro passo que dão é vesti-los e sustentá-los como eles nunca foram em seu país natal, ainda no estado de liberdade; e passam depois a mandar- lhes ensinar a doutrina cristã, e fazê-los compreender a excelência da religião que professamos, e finalmente a fazê-los de pagãos e idólatras católicos romanos (COUTINHO, 1838, p. 6).

O Bispo baseou sua defesa mormente no argumento religioso. Endossando o que dizia ser a opinião aturada pela Igreja, afirmou que, ainda que se abolisse o tráfico para o Brasil, os negros não seriam mais felizes, porque as nações africanas nunca deixariam de guerrear e tratar os prisioneiros como feras, comprando e comendo a carne de seus semelhantes, sem disso resultar proveito algum. Com a velha justificativa de teor econômico, colocou a pressão pela abolição do tráfico como resultante do medo que países europeus tinham da marcha da grandeza do Brasil, "agigantado império" ainda em embrião. Procurariam, então, destruir as bases da lavoura que fariam o Brasil chegar a uma categoria que nenhum outro Reino ou Império the poderia igualar. O tráfico deveria acabar gradualmente, 
à medida que fossem introduzidos avanços técnicos na produção, dispensando grande quantidade de mão de obra cativa.

Como Azeredo Coutinho, que conseguiu encontrar "princípios pios e humanos" em uma instituição como a escravidão, Bernardo Pereira de Vasconcelos viu a mesma como um elemento de civilização para o Brasil. Em discurso no Senado de 25 de abril de 1843, Vasconcelos queixou-se das "tendências barbarizadoras" que poderiam resultar da abolição do tráfico. Na fala de seu colega Antônio Pedro da Costa Ferreira, Barão de Pindaré, "Já a África civiliza!", um ditado que se tornou famoso à época e foi repetido exaustivamente pelos defensores da permanência do comércio de escravos, posto que a reprodução endógena era dificultada pelas altas taxas de mortalidade entre os nascituros e, portanto, ficava-se na dependência do fluxo de novos africanos pelo tráfico transatlântico, fonte mais segura para alimentar o sistema. A fala seguinte foi de Vasconcelos:

É uma verdade; a África tem civilizado a América, e veja o nobre senador os grandes homens da América do Norte, os mais eminentes, onde têm nascido; veja os outros todos que devem sua existência, o seu aperfeiçoamento aos paises que têm procurado em parte africanizar-se (VASCONCELOS, 1999, p. 268-269).

Endossando a declaração do Barão, o argumento do Senador mineiro era característico da postura geral de seu grupo político, o do Regresso (logo também conhecido como saquarema e Partido Conservador), muito comprometido com os interesses de grandes proprietários rurais e todo o complexo comercial que envolvia essa questão.

Vinte anos depois, o argumento segundo o qual a África civilizava o Brasil ecoou vivissimamente nas "Cartas a favor da escravidão" (1865), escritas pelo romancista e correligionário do Partido Conservador José de Alencar. Os tempos de Azeredo Coutinho, Vasconcelos e Alencar eram diferentes. Os primeiros escreveram antes da supressão do tráfico, o outro, o último, após a Lei de 4 de setembro de 1850, mais conhecida como Lei Eusébio de Queiroz, e todo o debate subsequente em torno da sobrevivência do cativeiro, mas todos partiram de uma justificativa para a manutenção do sistema escravista. Assinadas com o pseudônimo "Erasmo" e dirigidas ao Imperador D. Pedro II, as "Cartas" tinham um verniz pedagógico. Ao querer instruir o monarca, Alencar destrinçou sua teoria social que tinha por leitmotiv a tese de que o cativeiro civilizava desde os primórdios da humanidade, pois retirava o homem do estado bruto da natureza, permitindo-o caminhar rumo à vida comunitária e à cultura.

Alencar justificou a escravidão com quatro tipos de argumentos. No plano cultural, defendeu que nos tempos modernos a civilização acorria às regiões atrasadas moralizando seus habitantes por meio da escravização. Censurava, assim, o modo como se dava a escravidão nos Estados Unidos, para ele, uma distorção da função histórica do cativeiro, aproveitando para lançar mão de um argumento pró-escravista sempre aludido de que no Brasil o sistema era qualitativamente superior. Na questão político-social, sustentou que sem a escravidão africana e o tráfico que a realizou a América continuaria um deserto. Sobre o aumento pouco significativo da população se comparado, por exemplo, aos Estados Unidos, alegou que no Brasil se alforriava muito, o que dava um caráter especial ao cativeiro no País, permitindo maior inserção dos libertos na sociedade, inclusive, garantindo-lhe os direitos de cidadão (em caso de nascimento no Brasil, poderia votar nas eleições de primeiro grau), e ao seu filho a cidadania plena, igual aos brancos, com restrição censitária, não de cor.

O terceiro argumento, econômico, atribuiu à escravidão a missão de equilibrar a economia do País para honrar as dividas contraidas no exterior, e nisso não deixava de alfinetar as Repúblicas vizinhas, prenhes de convulsões, ao contrário da muito explorada imagem da Monarquia institucionalmente estável, como se o Brasil não tivesse também grandes problemas para conservar a "ordem". Como último argumento, ressaltou a contribuição do cativeiro para a formação da identidade nacional, a densidade cultural oriunda da mistura de povos (PARRON, 
2008, p. 20-28).

O núcleo dessa concepção exposta por Alencar esteve presente na base da defesa próescravista saida nos panfletos e nas obras mais sofisticadas de vários letrados e nos trabalhos de tantos outros estadistas do Império. Ainda no dia 13 de maio de 1888, enquanto a Regente Princesa Isabel segurava a pena para assinar a Lei Áurea, Senadores do Partido Conservador discursavam na tribuna condenando a Abolição como uma medida antieconômica, antissocial e anticonstitucional.

É preciso salientar que os posicionamentos não eram de todo coerentes ou cristalizados. Como ressaltou Jaime Rodrigues (2009, p. 302), as nuanças nas falas e nos escritos políticos permitem encontrar até quem defendia a expulsão dos africanos em nome da humanidade, da liberdade e da homogeneidade social, o que desfazia, por exemplo, todo o esforço explicativo de Alencar. Não se pode falar apenas em quem defendia a permanência do comércio sustentando-se pela lógica da propriedade e das finanças, ou quem condenava por ser um entrave à civilização.

O tráfico alimentava a escravidão. Sem hesitar, Varnhagen o timbrou de comércio de carne humana e propôs sua extinção. Quando escreveu a primeira parte do Memorial orgânico em fins de 1849, o Império se via às voltas para equacionar elementos em boa medida antagônicos, como honrar as exigências dos tratados internacionais assinados com a Inglaterra e conter a ação inglesa cada vez mais "invasiva" e desejosa desse cumprimento, lidar com a situação interna, os interesses envolvidos na prática centenária de traficar negros pelo Atlântico, vozes dissonantes na política, contra ou a favor, a reclamação dos proprietários em nome da demanda de braços para a lavoura. A conjuntura recomendava prudência no manejar dos fatores. O principal fator externo foi a exigência inglesa, respaldada em tratados assinados desde quando o Brasil era Colônia portuguesa. Como fatores internos, concorria a recorrente justificativa econômica, os supostos danos à moralidade, a "culpa" por epidemias e a opinião antiescravista de alguns atores políticos importantes.

A tese de que o trabalho escravo era responsável por danos morais à nação, além dos danos econômicos vinculados ao custo do escravo em relação a sua produtividade foi amplamente veiculada. Varnhagen compartilhou da ideia da impossibilidade de ser livre sem uma educação virtuosa, da incompatibilidade entre virtudes morais e a convivência com os vícios inerentes ao cativeiro.

A esse respeito, em 1831 o Senador pernambucano Antonio Luís Pereira da Cunha, Marquês de Inhambupe, opinou do alto da tribuna do Senado que o maior bem que resultaria da abolição da escravatura era arredar de "nós esta raça bárbara, que estraga os nossos costumes, a educação dos nossos filhos, o progresso da indústria, e tudo quanto pode haver de útil" (CUNHA apud SLENES, 1992, p. 66). Essa declaração é um exemplar dos mais contundentes acerca das propaladas indolência e corrupção dos costumes creditada aos africanos que atravessavam o oceano, que teve vida longa nos discursos políticos e nos trabalhos voltados para a questão do tráfico negreiro, talvez até mais do que a pressão inglesa, sofrendo variação no significado de acordo com quem a usava como argumento político.

Sentindo-se quase europeia, a elite imperial tinha até uma "língua pura" e perfilava os "benefícios" que ganhariam os traficados para o lado de cá do Atlântico: o clima mais ameno, a moral e os costumes civilizados a partir do convívio com os brancos. As "vantagens" não seriam, porém, reconhecidas por aqueles que, em troca, vingavam-se, promoviam fugas e arruaças e inoculavam degeneração e misérias na sociedade.

O seguinte excerto da História Geral representa bem o lugar de fala de Varnhagen, um legítimo defensor da propriedade e do bem do Estado:

Se os colonos escravos africanos concorriam a aumentar a riqueza pública com o seu trabalho, por outro lado pervertiam os costumes, por seus hábitos menos decorosos, seu pouco pudor, e sua tenaz audácia. A escravidão, como ela foi admitida entre nós, alheia à ternura da familia, endurece o coração dos escravos, os quais não querem ganhar inclinações que de um a outro momento 
Ihes sejam contrariadas, nem podem interessar-se tanto pela prosperidade de seu próprio senhor; visto que d'ela nada lhes cabe em sorte, desde o dia em que passam a outro dono.

Apesar disso é certo que o melhor amigo que tem o bom escravo é geralmente o seu amo e senhor. Não só por um lado a opinião e a religião o obrigam a não ser despótico e cruel, como o aconselha a isso o individual interesse; - o instintivo amor da propriedade. De modo que se pode afoitamente assegurar que a não encontrar dono, - a não passar a ser no Brasil escravo o colono negro boçal que chegava d'África, sem protetor algum natural, sem uma enxada sequer de seu com que revolvesse a terra, sem ninguém interessado a entendê-lo nas queixas de seus sofrimentos, devia perecer à míngua. O mesmo sucederia ainda hoje a muitos deles se momentaneamente os libertássemos, antes de os ir preparando para com o tempo fazer a seus descendentes o bem que seja compativel, em relação ao Estado e à família (VARNHAGEN, 1854, p. 185).

Todos esses males radicais eram vícios e misérias perniciosas ao País. Ai estão justificadas as considerações de Estado. O excerto dispensa grandes comentários, não era possivel que ignorasse as reais condições em que se dava a relação senhor-escravo e que o problema não era exatamente o trocar de dono. Mas Varnhagen foi cirúrgico na avaliação que fizera de uma virtual libertação. Aprovada a Lei de 13 de maio de 1888, sem grande empenho do Estado em elaborar projetos de integração social dos ex-escravos, eles realmente pereceram à míngua.

No Memorial orgânico, afirmou que,

Encaramos a questão dos escravos não pelo sentimentalismo, mas pelo patriotismo [...], porque tememos pelo futuro do Brasil, se continuamos a importar africanos. Foram considerações de Estado, mais que de leconomia polítical que pesaram em nossas opiniões (VARNHAGEN, 2016, p. 164).

É óbvio que obstar o tráfico incidia na economia política do País. A questão estava em que, na balança do autor, pesava mais o suposto perigo de revolta generalizada, por exemplo, do que eventuais perdas de lucro na lavoura. Para convencer os representantes da nação de seu ponto de vista nessa questão de máxima urgência, recordou exemplos históricos. Acompanhe a sequência de considerações do autor:

escuro e medonho vulcão que estão preparando ao Brasil os que, sob pretextos de aumentar os braços e a cultura da cana e do café, sustentam como indispensável o tráfico dos africanos. Egoistas insensatos! E sacrificais assim o futuro do vosso pais a um conto de réis de menos ou de mais para as alfândegas! Lede com reflexão a história da humanidade. Quem domina hoje ou antes desde o século de Luiz XI e de João II na Europa? A classe média, isto é, a gente não filha de algo, e por conseguinte os descendentes dos que poucos séculos antes eram servos; e tardaram tanto tempo porque não havia então constituições e as leis dos godos contra os escravos eram severíssimas. Quereis pois ver o vosso Brasil daqui a séculos igual ao continente da África fronteiro e vossos netos reduzidos talvez à condição de servos dos netos dos africanos?

Ora pois, tenhamos mais patriotismo e não atraiçoemos o futuro do Brasil.

A estas considerações respondem os negreiros: "Histórias! Sem o couro de Guiné, que seria do Brasil?"

Bárbaros! O Brasil seria então mais do Brasile menos dos negros! (VARNHAGEN, 2016, p. 160, grifo do autor).

Esse excerto é particularmente fértil para observar recursos retóricos importantes utilizados pelo autor na escrita do texto. Varnhagen poderia ter prontamente afirmado as ideias apresentadas no trecho selecionado, mas fez ao leitor perguntas para as quais tinha respostas. Com isso, queria provocar naquele uma reflexão que lhe interessava entretecer, conquistando sua simpatia e adesão. Trocar uma afirmação por uma questão é, segundo José Luiz Fiorin, um procedimento retórico intitulado "interrogação", em que o andamento discursivo é acelerado e o sentido intensificado ao fazer a exposição de um ponto de vista por meio de perguntas. Esse tipo de interrogação recebe o nome de "interrogação retórica", porque não são questões destinadas a obter uma informação desconhecida, mas a tornar o sentido mais forte (FIORIN, 2014, p. 184-185). O mesmo acontece com a substituição de uma afirmação por uma exclamação. No conjunto, 
esse reforço na defesa de suas proposições deixou também a marca de sua visão de mundo aristocrática ao conjecturar um virtual paralelo entre o que poderia ser o futuro do Império: se na Europa de então dominavam os descendentes dos antigos servos, não haveria a possibilidade de o Brasil vir a ser governando por descendentes de escravos? O medo de um Brasil todo negro, de uma transplantação da África para o Brasil e com isso a preponderância da "classe escrava", levou-o a condenar a conduta dos agentes do "infame comércio" que trocavam a tranquilidade do pais por um conto de réis, sacrificando o interesse público em favor do enriquecimento privado.

Mas o temor de uma suposta "africanização" ou "haitianização" do Brasil não deveria ser exclusivo do historiador. Nesse final da década de 1840 conviveu-se com o receio de uma rebelião de grandes proporções na região de maior concentração escrava do Império naquele momento, o Vale do Paraiba fluminense. O plano de rebelião escrava descoberto em 1848 envolvia vários municipios do Vale e gerou temor nas autoridades da Província do Rio de Janeiro (SLENES, 1992, p. 66). Coincidindo com o momento de maior pressão pelo fim do tráfico transatlântico, especulou-se que a Inglaterra estava a apoiar sedições. A respeito da possiblidade de rebelião generalizada, Varnhagen opinou que uma nação escravista poderia vencer o movimento dos cativos enquanto eles se achassem no ínfimo grau de rudeza, o que achava ser o caso dos escravos do Brasil, já que não tomaram parte nos últimos conflitos civis. Contudo, em não se melhorando suas condições, na medida em que as luzes se difundissem pelos escravos, a nação iria se debilitando, sendo muito dificil resistir a qualquer agressão (interna ou externa) contra sua integridade e mesmo independência.

Não era o caso, portanto, do governo descuidar. Para ele,

A escravatura dos africanos torna o país escravo de si próprio; pois como diz o M. de Maricá: o cativeiro apostema e tortura os escravos e seus senhores. É urgentíssimo impedir-se que entrem mais [...]. E cuidado que eles não dormem tanto como se pensa! Já tem feito seus ensaios em vários anos, no dia de Reis, em que se juntam por todo o Brasil, e só é para temer que uma vez se combinem a um tempo...

Para suprir seus braços, cumpre que se tomem providências acerca dos indigenas, fazendo que se tire destes o possivel proveito. Diremos adiante o único modo que vemos possivel de pronto para se os utilizarem, e acabarem-se as tendências do tráfico africano, sem que para isso despenda o Estado (VARNHAGEN, 2016, p. 120).

A escravidão seria o cancro do Brasil e a entrada de mais cativos o alimento para essa chaga. Não obstante sua frequência em textos políticos desde o final do século XVIII, aparentemente, o haitianismo, medo de no Brasil reeditar-se o ocorrido em São Domingos (Haiti) no século XVIII, funcionou mais como um argumento retórico, um espectro que rondava as consciências desses autores (recorria-se a ele para expressar uma preocupação), do que propriamente uma presença real na dinâmica brasileira da metade do século.

Conforme Alain El Youssef (2016, p. 143), no Brasil quase nada disso esteve presente por conta da dificuldade da circulação de notícias e de pessoas, já que as rotas das embarcações do Atlântico Sul pouco se cruzavam com as do Caribe e do Atlântico Norte. Como outros fatores que contribuiram estariam que os burocratas imperiais não recebiam pedidos de ajuda das autoridades coloniais francesas, o Pais recebeu poucos refugiados da ltha e nenhuma revolta escrava ocorrida no Império foi diretamente impulsionada por aquela. $\mathrm{O}$ uso teria tido finalidades políticas especificas, servindo a variados projetos e como crítica à oposição no poder. De todo modo, importa salientar que "reinterpretando os momentos de crise e turbulência entre senhores, políticos e autoridades, os cativos procuravam tirar proveito de tais situações segundo seus interesses" (SOARES; GOMES, p. 140).

Fantasma que pairava sobre as escrivaninhas e tribunas ou não, o medonho vulcão preparado pelos cativos era temivel sendo possibilidade real ou pesadelo letrado (e proprietário, em larguissima escala), por isso não deixou de assinalar eventos que evocavam: 
[...] ao santo grito de "liberdade, igualdade e fraternidade". Como se não fosse de bastante escarmento tudo quanto em França acabava de suceder, ao som deste grito, não faltaram na Bahia espíritos exaltados que de novo o invocaram; - esquecendo-se de que, quando numa província com tanta escravatura, a sua generosidade lograsse triunfo, libertando a todos os escravos, como prometiam, depressa, como se viu no Haiti, seriam vitimas destes, desenfreados e em muitíssimo maior número (VARNHAGEN, 1877, p. 292).

Varnhagen tinha ampla repulsa aos movimentos emancipacionistas. No Memorial, a listagem das sublevações escravas se seguiu com a dos cativos dos Citas, contada por Heródoto, em que esse povo se viu obrigado a ceder as terras e a emigrar, e as insurreições de Herdônio e Espártaco na Itália. Ainda citou Aristóteles, que no livro "Política" expôs a dificuldade de tratar os escravos, para que nem a brandura os fizesse insolentes, nem a dureza lhes excitasse vinganças. Todos esses casos eram exemplares para o Império cuidar a tempo de não "imitá-los", e nem precisava ir tão longe no tempo e no espaço, repisava que "Os exemplos da jovem América nos dão a cruel certeza de que a raça, ou a cor da pele, não fazem variar as tendências de todos os escravos", por isso aconselhava "a não deixar de consultar a verdadeira mestra da vida, como tão filosoficamente chama Cícero a história. Tratemos pois de ir suavizando, sem lesar os proprietários e a indústria do país" (VARNHAGEN, 1850, p. 8).

Outro mal, subproduto da escravidão, era a crença entre os estrangeiros de que o trabalho manual no Brasil era indigno, daí Varnhagen propugnar que não houvesse trabalho cativo nos departamentos fronteiriços, nas cidades com mais de dez mil habitantes e que escravos não fossem transportados por navios de cabotagem, nem servissem na Marinha. Em um registro que aponta a imagem que se tinha do Império nesse sentido, rumo ao posto de Residente no Paraguai, o historiador passou algum tempo no Uruguai e externou ao Imperador as impressões pouco edificantes que teve: livros escritos sem jeito, nenhuma organização ou legislação e nenhuma originalidade do país, reduzido a campos com um ou outro umbu, árvore que já conhecia da Europa. Desse modo, interessou-se em estudar o pais nos homens, sobretudo ouvindo-os. Mas o juizo mais interessante da missiva foi quando escreveu que "os orientais puros, quer blancos, quer colorados, são nossos inimigos do Brasil, e todos nos chamam Macacos" (VARNHAGEN, 1961, p. 269, grifo do autor).

As autoridades dos primeiros anos da Regência, da ala liberal moderada, mostraramse interessadas em executar a legislação recémaprovada pelo Parlamento brasileiro, resultando em uma declinação da entrada de cativos no início da década de 1830. Encaminhando-se para o final dessa década, com as mudanças de políticos ocupando as mais altas posições de poder, iniciou-se o chamado Regresso e, despeito dos altos custos diplomáticos, a resistência à aplicação da lei se intensificou. Nesse contexto, a Inglaterra não ficou assistindo ao planejamento de reabertura do comércio já clandestino. Chefes do Foreign Office, o Whig Henry John Temple Palmerston (1835-1841, 1846-1851) e o Tory George Hamilton-Gordon Aberdeen (1841-1846) não pouparam esforços para obstar a revogação da Lei de 7 de novembro de 1831 e dirimir o contrabando realizado com a anuência das altas instâncias do Governo Imperial e o apoio de diversos setores da população. Estima-se que aproximadamente $42 \%$ das importações de africanos para o Brasil nos três séculos de tráfico ocorreram apenas na primeira metade do século XIX, boa parte dessas ilegalmente após 1831, e que tinham por destino as fazendas de café do Sudeste. No tocante ao que se pensou em fazer com esses cativos, Beatriz Mamigonian (2017, p. 43) apontou que políticos foram a favor ou rejeitaram a ideia de manter os africanos resgatados do tráfico no Brasil, alguns propuseram que aqueles fossem reenviados à África.

Esta Lei, que ficou famosa pela alcunha de "para inglês ver", na realidade, foi para brasileiro ver e aproveitar. Outro aspecto interessante assinalado por Sidney Chalhoub: a riqueza e o poder dos cafeicultores, símbolo da grandeza da Monarquia ao longo do Segundo Reinado, foi viabilizado ao 
arrepio da lei, adquirindo escravos provenientes de contrabando, escravizando africanos livres, portanto (CHALHOUB, 2012, p. 35-37).

Segundo Tâmis Parron, o problema se avolumou na década de 1840, época de franca escalada pró-escravista, pois o acordo comercial anglo-brasileiro de 1826 (Convenção) estava previsto para acabar em 1842 (foi prorrogado para 1844) e o tratado antitráfico, também de 1826 e assinado entre Brasil e Inglaterra, expiraria em 1844. A situação inspirava cuidado nas negociações, a cessação do tráfico poderia significar a estagnação da produção agrícola com consequente diminuição da receita gerada pela exportação, em um momento em que o País saía do acordo que congelou as tarifas de importação (PARRON, 2009, p. 146).

A pressão mais incisiva da Inglaterra sobre o desmantelamento definitivo do tráfico atlântico para o Brasil, contudo, foi a aprovação, pelo Parlamento, em 8 de agosto de 1845, da Lei denominada de Trade Suppression Act ou Aberdeen Act, mais conhecida como Bill Aberdeen, referência à Lord Aberdeen. Cabe ressaltar que, apesar de estadistas e escritores ingleses terem retratado sua campanha como uma questão moral, já existia considerável literatura contemporânea atacando os motivos do tráfico. Pelo Bill de 1845, as comissões mistas estabelecidas no Rio de Janeiro e em Serra Leoa estavam autorizadas a proceder até o dia 13 de setembro do ano referido à adjudicação dos navios detidos em virtude da Convenção de 23 de novembro de 1826, assinada pelo Rei Jorge IV e D. Pedro I, cujos julgamentos estivessem pendentes e não foram decididos até 13 de março (Art. 1. $^{\circ}$ ). Também decretou que seria lícito ao alto tribunal do almirantado e a qualquer tribunal de vice-almirantado de S. M. dentro de seus dominios tomar conhecimento e julgar qualquer navio que fizesse o tráfico de escravos africanos em contravenção da Convenção, após a data de 13 de março (Art. $4^{\circ}{ }^{\circ}$ ) (BONAVIDES; AMARAL, 1996, p. 106-107).

A política britânica gerou inflamados protestos no Brasil, acirrando os ânimos daqueles que se punham na linha de frente pela defesa da honra nacional ultrajada. No "Protesto do Governo Imperial contra o Bill Aberdeen de 22 de outubro de 1845", Antônio Paulino Limpo de Abreu deu conta da "mais profunda mágoa" sentida por Sua Majestade o Imperador D. Pedro II com a aprovação e sanção como lei pela Rainha britânica. Em meio às justificativas pela expiração do prazo e as dificuldades de se chegar a um acordo razoável e justo entre os dois governos, o conselheiro não deixou de alegar que nação nenhuma poderia exercer ato de jurisdição sobre a propriedade e os indivíduos no território de outra (BNAVIDES; AMARAL, 1996, p. 112). O protesto brasileiro foi unânime, envolvendo a Chancelaria, o Parlamento e o Conselho de Estado, objetivando evitar maiores agravos e sensibilizar outros governos, estendendo-se na ordem jurídica (a Inglaterra não podia aplicar leis internas a cidadãos estrangeiros), política (atentado à soberania e propriedade), econômica e diplomática (o Bill violava o direito internacional e impunha a vontade do mais forte por método violento).

A reclamação do "estado miserável" em que se encontrava o País, ultrajado pelos "meios violentos" da politica britânica, varria os quatro cantos das Assembleias ao redor do Império. Muito antes de se chegar a essa conjuntura, o Deputado pela Província de Goiás, Raimundo José da Cunha Mattos, já clamava que "o comércio de escravos deve acabar, mas deve acabar quando assim o quiser a nação brasileira, livre, soberana e independente dos caprichos e da vontade do governo de Inglaterra" (apud RODRIGUES, 2009, p. 326), mostrando que a construção da "nação brasileira" passava pela consolidação do poder senhorial em uma sociedade marcada pelas restrições de cidadania plena. Quase vinte e cinco anos depois da fala de Mattos a premissa era a mesma, o tráfico interessava especialmente àquele grupo.

A Lei inglesa também complicaria os negócios do Império na região do Prata, que já se constituia em uma área de conflito entre o Brasil e os vizinhos platinos. Mais tarde, as tensões e os conflitos de interesses na região levariam à deflagração da Guerra do Paraguai ou 
Guerra da Triplice Aliança, entre Brasil, Argentina, Uruguai e Paraguai. Com ou sem "paixão de partido", a promulgação do Bill teria atacado de frente a soberania da nação brasileira, usando do "despotismo da força" para conseguir o que a pena não honrou, e as consequências batiam à porta do Império, ou melhor, aprisionavam navios. Na realidade, 1850 já foi uma extrapolação do limite máximo que deveria ter sido 1830, banido por tratado internacional e proibido por uma lei nacional do ano seguinte.

Finalmente aprovada em 4 de setembro de 1850, a Lei Eusébio de Queiroz estabeleceu que as embarcações brasileiras encontradas em qualquer parte e as estrangeiras encontradas nos portos, enseadas, ancoradouros ou mares territoriais do Brasil trazendo escravos a bordo ou tendo-os desembarcado, seriam apreendidas pelas autoridades competentes ou pelos navios de guerra brasileiros, sendo consideradas importadoras de escravos. Para o caso das embarcações sem escravos a bordo ou que não os tivessem desembarcado proximamente, contudo que fossem encontrados indícios de que eram empregadas no tráfico, valia a mesma regra (Art. 1. ${ }^{\circ}$ ). A importação de escravos no território do Império seria considerada pirataria, punida pelos seus Tribunais. A tentativa e a cumplicidade na prática criminosa seriam punidas segundo o Código Criminal (Art. $4^{\circ}$ ), e os escravos apreendidos, reexportados por conta do Estado, para os portos de onde vieram ou qualquer outro ponto fora do Império, julgado mais conveniente pelo Governo. Enquanto não se desse a reexportação, trabalhariam tutelados pelo governo, sendo proibida a concessão de seus serviços a particulares (Art. 6..$^{\circ}$ (COLEÇÃO DAS LEIS DO IMPÉRIO DO BRASIL DE 1850, 1851, p. 267-268).

\section{Extinguindo o "infame comércio"}

Redigida em 1849, a primeira parte do Memorial orgânico trouxe a proposta de supressão do tráfico, já a segunda parte, mencionou a legislação aprovada, do que se sucede que fora escrita após a data de 4 de setembro de 1850. Para Varnhagen, - Império meteu uma lança em África com essa Lei, todavia, além de gravosa para o Estado, não passaria de um simples tiro de azagaia que não impediria a ação dos piratas ao longo da extensa costa. Necessitava-se não uma lei inútil ou absurda que determinasse o enforcamento do fazendeiro criminoso encontrado com alguns negros novos, mas uma que não infligisse totais prejuizos para os donos de escravos e da indústria do Brasil, logo,

\begin{abstract}
A lei que devemos fazer e promulgar, a lei que unicamente é capaz de dar um golpe mortal no tráfico ilicito da Costa, é ao mesmo tempo a mais essencial. reclamada pela civilização e pela política, que necessitamos para melhorar a condição dos nossos escravos. Essa lei é a que deve declarar que no Brasil os escravos deixam de ser mercadoria; continuam servos dos seus respectivos senhores, e a prestar-lhes a mesma obediência, os mesmos serviços, mas não podem mais ser vendidos como se vende um animal (VARNHAGEN, 1850, p. 9. grifo do autor).
\end{abstract}

Não havendo mais mercado de carne humana, os bucaneiros de Guiné iriam contrabandear para outros mares. Com relação ao intenso contrabando que se seguiu ao decreto, que taxava como ilícito o comércio atlântico de escravos para o Brasil, Varnhagen acrescentou que fosse dado um prazo qualquer de tolerância para essas compras e vendas de cativos, mas findado esse prazo não se vendesse mais. Cuidou também em ressalvar que no primeiro departamento (Fronteira do sul, do Uruguai, meridional ou outro nome), nas ilhas da costa e outras regiões do Império não deveria ser permitida a escravatura, para já irem ensaiando os novos sistemas de colônias europeias.

A lei protestada pelo historiador era mais bem traçada. Expirado o prazo de tolerância para compras e vendas, cada senhor deveria inventariar seus escravos sob pena de perdêlos. Os que precisassem se desfazer dos que conservava poderia passá-los ao Estado mediante uma indenização a ser fixada pela lei que, ao mesmo tempo, era responsável por promulgar uma tabela reguladora dos valores dos cativos segundo sua idade, ocupação etc., para que os mesmos pudessem ser resgatados por algum protetor ou comprar sua alforria, no que convinha serem ajudados a juntar algum pecúlio. 
Como método preventivo para não favorecer a propagação da raça africana e cravar de vez um punhal na tremenda hidra da escravidão negra, que fosse decretada a liberdade de todo filho de escrava nascido de 1853 em diante, ao completar 12 anos de idade. A prudência recomendava uma abolição gradual, pois "matá-la de um tiro equivalia a soltá-la, e solta ela nos devoraria...", além de "ou restringir muito os direitos de toda raça que se está libertando, ou obrigar os libertos, para entrarem neste gozo, a deixarem o país, ou impedir-lhes que vão muitos morar em povoações etc." (VARNHAGEN, 1850, p. 9-10, grifo do autor). Para acabar com a escravidão, colocou um prazo para dali (1849) a vinte ou trinta anos, que ficasse no Brasil apenas os nascidos livres, ainda que demorasse quarenta anos.

Em 1854, Varnhagen tratou da jurisprudência da escravidão tal como existente no Brasil:

passando tais gentes ao Brasil, com as condições da escravidão romana; isto é, de serem coisa venal ou bem móvel, melhoravam elas de sorte; bem que fato de os escravizar era injusto, principalmente por não ser empreendido por ideia alguma filantrópica, e pelo contrário dar em resultado um insulto à humanidade, pelo ataque feito a um tempo ao individuo, à familia e ao estado donde eram arrancados (VARNHAGEN, 1854, p. 184).

A reflexão a esse respeito continuou no Tomo Il da História Geral, em que uma reforma de maior amplitude foi mencionada, a necessidade que:

se operasse no Brasil a importante reforma, que ele ainda hoje reclama, da conversão da escravatura, com as condições da grega e romana pagã, na servidão de gleba, fixa ao território, garantindo a família, e filha do cristianismo, como passo para a emancipação lenta, - única que pode operar-se sem comprometer a nacionalidade. Tristes devem ser por certo as consequências de se embotar no coração do pobre Africano os sentimentos mais ternos da humanidade, separando, com as vendas, os pais dos filhos, os maridos das suas mulheres, o fiel servidor do menino que acompanhara na infância e a quem velara, na esperança de vir algum dia a encontrar nele um senhor amigo e grato. Sem liberdade individual, sem os gozos de familia, sem esperanças de associar-se por si ou pelos filhos e netos à glória da pátria, que não fixa um século para a sua redenção social, não há que esperar do homem mui nobres sentimentos... (VARNHAGEN, 1857, p. 93).

Varnhagen não deu grande latitude a essa discussão de cunho jurídico no Memorial orgânico, mas ao falar na eventual lei que estabelecesse que escravo deixava de ser mercadoria, portanto, coisa venal ou bem móvel, podendo passar de um dono para outro, era o cerne dessa questão não bem esmiuçada talvez pelo caráter mais sintético da segunda parte do opúsculo, na qual propôs essa ideia. A confirmação pode ser vista em nota de rodapé da edição de 1851, quando indicou: "Julgamos [...] que sobretudo se reduzem a ir pouco a pouco acabando com a venda dos escravos, fazendo que eles continuem sim servos, mas deixem de ser cousa venal" (VARNHAGEN, 1851, p. 393).

O tráfico brasileiro de escravos foi abolido. A pressão inglesa, mas também o medo de rebeliões, o surto de febre amarela associado com o tráfico, uma opinião interna antiescravista. A nova conjuntura levou os saquaremas a implementar uma política contrária aos interesses imediatos de muitos senhores de escravos ao aprovar o cessar do comércio ilegal, mas, paradoxalmente, foi consolidado um novo tipo de escravidão. Para llmar de Mattos, a "derrota" dos conservadores acabou se tornando uma "quase vitória" (MATTOS, 1987, p. 231-245), não é demais recordar que a Lei levou o nome de Eusébio de Queiroz, um componente da "trindade" que assumiu o Ministério em 1848, comprometido com o projeto de fortalecimento/ centralização do Estado imperial.

O fim do tráfico significou a construção de um novo tipo de escravidão, daí falar-se em uma "política da segunda escravidão", isto é, uma rede de alianças políticas e sociais costuradas em favor da estabilidade institucional da escravidão, empregando órgãos máximos do Estado nacional brasileiro em benefício dos interesses das classes senhoriais, constituindo o que Ricardo Salles chamou de "escravismo nacional" (SALLES, 2011) que, em larga medida, esteve na raiz e dependeu da formação do Estado nacional.

A decisão de extinguir o tráfico explica-se por 
razões internas e cálculos de política externa. Convinha cessá-lo por motivos humanitários e estratégicos como dissipar o contencioso com a Inglaterra, viabilizar os planos de intervenção contra Rosas, que tinha o apoio do representante britânico em Buenos Aires, e eliminar o principal obstáculo ao incremento da imigração livre, isto é, decisões possiveis com o fortalecimento do Estado e a mudança da opinião pública (CERVO; BUENO, 2008, p. 82). O voto de Paula Souza, meses antes da aprovação da Lei, foi mais um a observar a margem de segurança a ser respeitada:

Reconheço quanto é infeliz um país que teve a desgraça de ter em si a escravidão e escusado me parece provar uma verdade que nenhum homem de senso desconhece; mas não sendo nós que motivamos tal desgraça, não sendo portando culpados dela, temos entretanto o dever de minorá-la e de trabalhar com afinco, mas com prudência, para vencê-la; é porém isso obra do tempo, e de um zelo esclarecido e incansável; o tráfico será dificilimo acabar, enquanto durar a escravidão, muito mais sem meios substitutivos para o trabalho; é pois esta uma questão conexa; é questão que deve ser tratada com a mais alta sabedoria política, e não só com sentimentos filantrópicos [...] (ANAIS DO SENADO DO IMPÉRIO DO BRASIL, 1978, p. 52-53).

O discurso do Senador refletia bem a tônica que as autoridades públicas imperiais queriam imprimir: o tráfico cessaria quando o Brasil decidisse de forma soberana.

Olhando para trás, em 1877 Varnhagen escreveu com um tom de lamentação ao imaginar quão adiantado estaria o Brasil naquele momento se tivesse adotado as medidas que propôs quase trinta anos antes. Mencionou a Lei de 28 de setembro de 1871 (mais conhecida como Lei do Ventre Livre), que libertou o ventre escravo vinte anos depois do que ele tinha proposto, e o evento que ficou conhecido como Questão Christie, nome em alusão ao Ministro Plenipotenciário inglês William Christie, que consistiu em dois incidentes envolvendo a Marinha britânica em território brasileiro e acabou levando ao rompimento das relações diplomáticas entre Brasil e Inglaterra de 1863 a 1865, "uma humilhação [...], às barbas da própria capital" (VARNHAGEN, 1877. p. 16), em sua avaliação.
Ainda sobre a escravidão, arrematou: Sobre este ponto mais teriamos que di-
zer, se estivéssemos em sessão secreta.
Não trouxemos, segundo o costume,
para exemplo a atual monarquia negra
da América, porque ai os fatos tem outro
alcance. O triunfo exclusivo dos africanos
no Haiti é um aviso a todos os pardos da
América, sobre a sorte que os esperaria,
se eles se unissem aos negros contra
os brancos (VARNHAGEN, 1850, p. 10).

Ao lado do gracejo com as sessões secretas do Senado naquele ano (1850), Varnhagen confirmou que, mais que outra reflexão proveniente da formação militar, sua proposta de construção nacional (da qual o fim do tráfico fazia parte) se baseava na experiência como historiador.

\section{Considerações finais}

Ao propor o fim do tráfico, Varnhagen demonstrou que estava atualizado com a agenda política do Império do Brasil em meados do século XIX. Muitos homens de letras o defendiam no período, assemelhando-se os motivos como o discurso da corrupção moral e a pressão britânica.

A extinção do comércio era contra os interesses da elite do Império, que tinha no trabalho escravo a matriz de seu fausto e prestígio. Mesmo propondo uma libertação gradual, como tantos outros de seu tempo, essa também não estava na agenda dos senhores de grandes plantéis de cativos. Aliás, Varnhagen os ironizou no Memorial orgânico. Entrea pena das pessoas que "pensavam" a nação, a ação política que governava e a dinâmica da sociedade (o costume, por exemplo) ia muita distância.

\section{Referências}

ANAIS DO SENADO DO IMPÉRIO DO BRASIL. SesSão de 3 de julho de 1850. Brasília: Senado Federal, Subsecretaria de Anais, 1978.

BASTOS, Aureliano Cândido Tavares. Cartas do Solitário. 4. ed. São Paulo: Ed. Nacional; Brasilia: INL, 1975.

BONAVIDES, Paulo; AMARAL, Roberto. Textos politicos da História do Brasil. v. 2. Brasilia: Senado Federal, Subsecretaria de Edições Técnicas, 1996.

CERVO, Amado Luiz; BUENO, Clodoaldo. Economia, população e política externa. In: CERVO, Amado Luiz; BUENO, Clodoaldo. História da política exterior do Brasil. 3. ed. Brasilia: Editora Universidade de Brasilia, 2008. 
CHALHOUB, Sidney. Escravismo. In: CHALHOUB, Sidney. A força da escravidão: ilegalidade e costume no Brasil oitocentista. São Paulo: Companhia das Letras, 2012.

COLEÇÃO DAS LEIS DO IMPÉRIO DO BRASIL DE 1850. Lei de 4 de setembro de 1850. Estabelece medidas para a repressão do tráfico de africanos neste Império. TOMO XI. Parte I. Rio de Janeiro: Tipografia Nacional, 1851

COSTA, Hipólito José da. Escravatura no Brasil. In: COSTA, Hipólito José da. Hipólito José da Costa. São Paulo: Ed. 34, 2001.

COUTINHO, José Joaquim da Cunha de Azeredo. Memória sobre o comércio dos escravos, em que se pretende mostrar que este tráfico é, para eles, antes um bem do que um mal. Rio de Janeiro: Tip. Imp. e Const. de J. Villeneuve e Comp., 1838

FEIJÓ, Diogo Antônio. Diogo Antônio Feijó. São Paulo Ed. 34, 1999.

FIORIN, José Luiz. Figuras de troca II: exclamação, interrogação; Reticência ou aposiopese. In: FIORIN, José Luiz. Figuras de retórica. São Paulo: Contexto, 2014.

LYNCH, Christian Edward Cyril. Quando o regresso é progresso: a formação do pensamento conservador saquarema e de seu modelo político (1834-1851). In: BOTELHO, André; FERREIRA, Gabriela Nunes (org.). Revisão do pensamento conservador: ideias e política no Brasil. São Paulo: Hucitec: Fapesp, 2010.

MAMIGONIAN, Beatriz G. Africanos livres: a abolição do tráfico de escravos no Brasil. São Paulo: Companhia das Letras, 2017

RODRIGUES, Jaime. O fim do tráfico transatlântico de escravos para o Brasil: paradigmas em questão. In: GRINBERG, Keila; SALLES, Ricardo. O Brasil Imperial: 1831-1889. v. 2. Rio de Janeiro: Civilização Brasileira, 2009

PARRON, Tâmis Peixoto. Introdução. In: ALENCAR, José de. Cartas a favor da escravidão. São Paulo: Hedra, 2008.

PARRON, Tâmis Peixoto. A politica da escravidão no Império do Brasil, 1826-1865. Dissertação (Mestrado em História Social). Faculdade de Filosofia Letras e Ciências Humanas, Universidade de São Paulo, 2009

SALLES, Ricardo. Abolição no Brasil: resistência escrava, intelectuais e política (1870-1888). Revista de Indias, Coimbra, v. LXXI, n. 251, 2011. DOI: https://doi. org/10.3989/revindias.2011.010.

SILVA, José Bonifácio de Andrada e. Projetos para o Brasil. São Paulo: Companhia das Letras, 1998.

SLENES, Robert W. "Malungu, ngoma vem!": África coberta e descoberta no Brasil. Revista USP. São Paulo, n. 12, p. 48-67, dez. 1991-fev. 1992. DOI: https:// doi.org/10.11606/issn.2316-9036.voi12p48-67.

SOARES, Carlos Eugênio; GOMES, Flávio. Sedições, haitianismo e conexões no Brasil escravista: outras margens do Atlântico negro. Novos Estudos, São Paulo, n. 63, p. 131-144, jul. 2002.
VARNHAGEN, Francisco Adolfo de. Memorial orgânico. Em que se insiste sobre a adoção de medidas de maior transcendência para o Brasil. Madrid: Imprensa da Viúva de D. R. J. Dominguez, 1850.

VARNHAGEN, Francisco Adolfo de. Memorial orgânico oferecido à nação. Guanabara, revista mensal, artistico, científica e literária, Rio de Janeiro: Tipografia de Paula Brito, p. 356-370, 382-402, out./nov. 1851

VARNHAGEN, Francisco Adolfo de. História Geral do Brasil. TOMO I. Madri: Imp. da V. de Dominguez, 1854.

VARNHAGEN, Francisco Adolfo de. História Geral do Brasil. TOMO II. Madrid: Imprensa de J. del Rio, 1857.

VARNHAGEN, Francisco Adolfo de. História Geral do Brasil. TOMO II. 2. ed. Rio de Janeiro: E. \& H. Laemmert, 1877.

VARNHAGEN, Francisco Adolfo de. A questão da capital: maritima ou no interior? Viena: Imp. do filho de Carlos Gerold, 1877.

VARNHAGEN, Francisco Adolfo de. Correspondência ativa. Rio de Janeiro: INL, 1961

VARNHAGEN, Francisco Adolfo de. Memorial orgânico que à consideração das Assembleias geral e provinciais do Império, apresenta um brasileiro. Dado a luz por um amante do Brasil. Brasilia: FUNAG, 2016.

VASCONCELOS, Bernardo Pereira de. Bernardo Pereira de Vasconcelos. São Paulo: Ed. 34, 1999.

YOUSSEF, Alain El. Domínio liberal e critica ao tráfico negreiro, 1831-1835. In: YOUSSEF, Alain El. Imprensa e escravidão: política e tráfico negreiro no Império do Brasil (Rio de Janeiro, 1822-1850). São Paulo: Intermeios; Fapesp, 2016.

\section{Ana Priscila de Sousa Sá}

Mestra em História pela Universidade Federal do Maranhão (UFMA, São Luís, MA, Brasil).

\section{Endereço para correspondência}

Ana Priscila de Sousa Sá

Universidade Federal do Maranhão

Av. dos Portugueses, 1966, CCH, Bloco I, s/n, térreo

Bacanga, 65080-805

São Luis, MA, Brasil 